\title{
Intestinal helminth communities of Podarcis bocagei and Podarcis carbonelli (Sauria: Lacertidae) in NW Portugal
}

\author{
M.A. GALDÓN ${ }^{1}$, V. ROCA ${ }^{1 *}$, D. BARBOSA ${ }^{2,3}$, M.A. CARRETERO ${ }^{3}$ \\ ${ }^{1}$ Departament de Zoologia (Parasitologia Animal), Facultat de Ciències Biològiques, Universitat de València, Dr. \\ Moliner, 50, 46100 Burjassot, València, Spain, E-mail: Vicente.roca@uv.es; ${ }^{2}$ Instituto Cavanilles de Biodiversidad y \\ Biología Evolutiva, Universitat de València. Apartado 22085, 46071 Paterna, València, Spain; ${ }^{3}$ Centro de \\ Investigação em Biodiversidade e Recursos Genéticos (CIBIO/UP), Campus Agrário de Vairão. 4485-661 Vairão, \\ Portugal
}

\begin{abstract}
Summary
A survey of gastrointestinal helminth communities of Podarcis bocagei and Podarcis carbonelli (Sauria: Lacertidae) from NW Portugal was conducted to determine the prevalence, intensity and diversity of intestinal parasites in these lizards. A few parasite species were found in both hosts, their prevalences, mean intensities and abundances of infection being low or very low. Low values of richness and abundance of parasite species were also found in the helminth infracommunities of individuals of both host species. These low values of parameters of infection and diversity are discussed and compared between both host species and among other Iberian lacertid lizards.
\end{abstract}

Key words: helminth communities; lizards; Iberian Peninsula

\section{Introduction}

Among the four species of lizards of the genus Podarcis currently recognised in the Iberian Peninsula, two of them are endemic to the Western part of this region, Podarcis bocagei Seoane, 1884 and P. carbonelli Pérez-Mellado, 1981 (Pleguezuelos et al., 2002). Both were considered conspecifc since the later was described as a subspecies of the former (Pérez-Mellado, 1981). Nevertheless, researches on morphology (Harris \& Sá Sousa, 2001), genetic divergence (Harris \& Sá Sousa, 2001, 2002; Harris et al., 2002) and behaviour (Barbosa et al., 2005) recently showed that $P$. carbonelli must be considered as a distinct species (Sá Sousa \& Harris, 2002). Another evidence in favour to consider them as different species is their pattern of geographical distribution (Harris \& Sá Sousa, 2001). Both forms live in western Iberian Peninsula, the river Douro being the main geographical barrier separating $P$. bocagei
(N of Douro) from P. carbonelli (S of Douro) (Sá Sousa, 2001). However, $P$. bocagei also has a small range south of the river in the area of the Douro Litoral province (Portugal) which constitutes a contact zone between both species. In some localities in which both species have been found in strict syntopy the species maintain their identity (Carretero et al., 2002). A possible biogeographic scenario would be a recent invasion of $P$. bocagei south of the Douro due to human interference (Sá Sousa, 2001).

Studies on helminth fauna of continental Iberian lizards of the genus Podarcis are partial and scarce (Roca et al., 1986a; García-Adell \& Roca, 1988), with limited helminthological data for $P$. carbonelli from the Spanish Central System (Roca et al., 1989, as P. bocagei carbonelli) and none for $P$. bocagei. Thus, this work represents an opportunity to know for the first time the infracommunities and the component community of $P$. bocagei and to complete the knowledge on the helminth communities parasitizing $P$. carbonelli. We also have an excellent opportunity to: (i) compare the helminth communities of both hosts in a peculiar contact area; and (ii) compare the helminth communities of $P$. bocagei and $P$. carbonelli with those of other lacertid lizards of the Iberian Peninsula.

\section{Material and Methods}

Sampling was carried out in three coastal localities from the Douro litoral, NW Portugal: Espinho-Granja, UTM squares 29T NF24 and NF34, for both hosts; Torreira near Aveiro, 29T NF21, for $P$. carbonelli and Mindelo-Vila Chã, 29T NF27, for P. bocagei. All three sites were geographically close (within a range of $40 \mathrm{~km}$ ) and harboured similar habitats, humid dunes covered by psammophilic vegetation (see Carretero et al., 2002 for a more detailed

\footnotetext{
* Corresponding author
} 
description). Climate regime was maritime Atlantic with warm mid-summers and mild, rainy winters; annual temperature averaged $12^{\circ} \mathrm{C}$ and total annual precipitation was 1000 - 1200 mm (Direcção Geral do Ambiente, 1995).

In all, 249 specimens of $P$. bocagei and 257 of $P$. carbo$n e l l i$ were collected. Lizards were immediately carried to the laboratory, sacrificed and frozen. These specimens were used not only for this study but also for analysing the cycles of gonads and fat reserves (Carretero et al., submitted a,b) as well as morphometrics (Carretero et al., 2003; Kaliontzopoulou, 2004) and trophic ecology (in progress). Digestive tracts were fixed in $70 \%$ alcohol prior to examination. Helminths were removed, washed, fixed and mounted according to standard techniques (for details see Roca, 1985). Parasites were identified, when possible, to species, and the number and location of individuals of each species were recorded.

The use of descriptive ecological terms followed Bush et al. (1997). Brillouin's index was used for calculating diversity according to Magurran (2004). A prevalence of 10 $\%$ was adopted as the upper limit for identifying satellite species (Kennedy \& Bakke, 1989). Species with prevalences $10 \%<\mathrm{p}<30 \%$ were assigned as secondary species
(Hanski, 1982; Roca, 1993).

\section{Results}

A total of 5 helminth species were recovered from both hosts (1 Trematoda, 1 Cestoda, and 3 Nematoda). The nematode Spauligodon carbonelli was found at the end of the large intestine (rectum), and the remaining species were found in the small intestine. The trematode Brachylaima sp. and the nematode Spirurida gen. sp. were recorded as larval forms whereas the other species were adults.

The total number of parasite species and the infection parameters for each host species are shown in Tables 1, 2 respectively. Both host species did not harbour identical parasite communities, although compositional similarities do exist being absent only Spirurida gen. sp. in the helminth community of $P$. carbonelli (see Tables 1,2 ). The overall prevalence of infection was $13.7 \%$ in $P$. bocagei, and $14 \%$ in $P$. carbonelli.

Only Skrjabinelazia hoffmanni from $P$. bocagei showed 10 $\%$ prevalence. All the remaining species infected less than $10 \%$ of the host populations. Tables 3 shows the diversity parameters for the helminth infracommunities of both hosts.

Table 1. Infection parameters of helminth species parasitizing Podarcis bocagei in NW Portugal $(\mathrm{n}=249)$

\begin{tabular}{|c|c|c|c|c|}
\hline Helminth species & Site & Prevalence $(\%)$ & Mean Intensity* & Mean Abundance* \\
\hline DIGENEA & & & & \\
\hline $\begin{array}{l}\text { Brachylaima sp. } \\
\text { CESTODA }\end{array}$ & intestine & 0.4 & - & - \\
\hline Oochoristica gallica & intestine & 2.4 & $\begin{array}{l}2.8 \pm 2.6 \\
(1-8)\end{array}$ & $\begin{array}{l}0.07 \pm 0.6 \\
(0-8)\end{array}$ \\
\hline NEMATODA & & & & \\
\hline Skrjabinelazia hoffmanni & intestine & 10.0 & $\begin{array}{r}4.0 \pm 5.6 \\
(1-27)\end{array}$ & $\begin{array}{l}0.4 \pm 2.1 \\
\quad(0-27)\end{array}$ \\
\hline Spauligodon carbonelli & caecum & 0.4 & - & - \\
\hline Spirurida gen. sp. & intestine & 0.4 & - & - \\
\hline
\end{tabular}

* Values are given as the mean $\pm \mathrm{SD}$ with the range in parentheses

Table 2. Infection parameters of helminth species parasitizing Podarcis carbonelli in NW Portugal $(\mathrm{n}=257)$

\begin{tabular}{|c|c|c|c|c|}
\hline Helminth species & Site & Prevalence (\%) & Mean Intensity* & Mean Abundance* \\
\hline \multicolumn{5}{|l|}{ DIGENEA } \\
\hline Brachylaima sp. & intestine & 1.2 & $\begin{array}{r}4.7 \pm 6.4 \\
(1-12)\end{array}$ & $0.05 \pm 0.8$ \\
\hline \multicolumn{5}{|l|}{ CESTODA } \\
\hline Oochoristica gallica & intestine & 1.2 & $\begin{array}{c}2.7 \pm 1.5 \\
(1-4)\end{array}$ & $0.03 \pm 0.3$ \\
\hline \multicolumn{5}{|l|}{ NEMATODA } \\
\hline Skrjabinelazia hoffmanni & intestine & 4.3 & $\begin{array}{c}1.5 \pm 0.5 \\
(1-2)\end{array}$ & $\begin{array}{c}0.06 \pm 0.3 \\
(0-2)\end{array}$ \\
\hline Spauligodon carbonelli & caecum & 7.8 & $\begin{array}{r}8.8 \pm 9.0 \\
(1-32)\end{array}$ & $\begin{array}{r}0.7 \pm 3.4 \\
(0-32)\end{array}$ \\
\hline
\end{tabular}

* Values are given as the mean \pm SD with the range in parentheses 
Table 3. Overall diversity parameters of the helminth infracommunities from Podarcis bocagei and P. carbonelli in NW Portugal

\begin{tabular}{lccccc}
\hline Host & $\mathrm{n}$ & $\begin{array}{c}\text { No. of helminth } \\
\text { species/host* }\end{array}$ & $\begin{array}{c}\text { No. of } \\
\text { helminths/host* }\end{array}$ & Brillouin's index* & $\begin{array}{c}\text { Proportion of } \\
\text { sample with 0 or 1 helminth species }\end{array}$ \\
\hline P. bocagei & 249 & $\begin{array}{c}0.14 \pm 0.34 \\
(0-1)\end{array}$ & $\begin{array}{c}0.49 \pm 2.19 \\
(0-27)\end{array}$ & 0 & 1 \\
P. carbonelli & 257 & $\begin{array}{c}0.14 \pm 0.36 \\
(0-2)\end{array}$ & $\begin{array}{c}0.83 \pm 3.5 \\
(0-32)\end{array}$ & $\begin{array}{c}0.001 \pm 0.02 \\
(0-0.34)\end{array}$ \\
\hline
\end{tabular}

* Values are given as the mean $\pm \mathrm{SD}$ with the range in parentheses

\section{Discussion}

The presence of Brachylaima sp. (metacercariae) in 3 of the examined lizards must be considered as atypical, probably due to ingestion of snails that are intermediate hosts for this trematode. Terrestrial gastropods and rodents are intermediate and definitive hosts, respectively, in the life cycle of Brachylaima spp. (González-Moreno, 2002). These snails are not usual prey of $P$. bocagei and $P$. carbonelli (Pérez-Mellado, 1982, 1983) although they are sporadically consumed in the populations analysed (unpubl. data). Inmature forms of Brachylaima were reported previously in $P$. carbonelli from the Spanish Central System (Roca et al., 1989), and also in Podarcis lilfordi and P. pityusensis from the Balearic Islands (Western Mediterranean), in all cases with low prevalences $(0.9 \% ; 0.8 \%$; $0.2 \%$, respectively) (Roca et al., 1989; Roca \& Hornero, 1994).

The remaining helminths, are species usually found as parasites of lacertid lizards and other reptile hosts. S. carbonelli can be considered as Podarcis specialist (Edwards \& Bush, 1989; Roca \& Hornero, 1994), since it only parasitizes hosts of this genus (García-Adell \& Roca, 1988; Roca et al., 1989). Oochoristica gallica, Sk. hoffmanni, and Spirurida gen. sp. (larvae) are generalist species, because they have been also found in other saurian hosts (Li, 1934; Dollfus, 1954; Sharpilo, 1976; Roca \& Hornero, 1994; Martin \& Roca, 2004).

Most helminth species occurred at low prevalence. The nematode $S k$. hoffmanni can be considered as a secondary species in the component community of $P$. bocagei, whereas the remaining helminths are satellite species. All the helminths are satellite species in the community of $P$. carbonelli. There are no core species (prevalence of infection $30 \%$ or higher, see Roca, 1993) in either hosts in these populations. The low values of prevalences and mean intensities of infection (Tables 1 and 2) indicate that many members of the helminth infracommunities occur only irregularly and occasionally (Martin \& Roca, 2005). Only the nematode $S k$. hoffmanni appears to be a common parasite of $P$. bocagei. This agrees with the typical pattern of helminth infection in many reptiles, i. e., few species occur frequently, few species occur with moderate prevalence (e. g. S. hoffmanni in P. carbonelli, S. carbonelli in both hosts), and many species are rare (Aho, 1990; Martin \& Roca, 2005).

Values of diversity index (Table 3 ) for both hosts have been revealed as the poorest of all values known for eura- sian reptiles. Thus, Sanchis et al. (2000) found "extremely poor infracommunities" in Lacerta (Zootoca) vivipara from the Pyrenees (Spain) (mean value of Brillouin's index of diversity $=0.0025 \pm 0.029$, range $=0-0.34$ ). Nevertheless, helminth infracommunities of $P$. bocagei and $P$. carbonelli showed even lower diversity. The causes of the very low diversity for $L$. (Z.) vivipara were the small body size, ecological isolation and few interactions with other reptile and amphibian species in the population studied (Sanchis et al., 2000). It seems that this pattern is similar in $P$. bocagei and P. carbonelli from NW Portugal. Sandy areas have been revealed as zones where recruitment of parasites by lizard hosts is low; thus Roca et al. (1986a,b) found very poor helminth communities in lizards such as Psammodromus algirus, Psammodromus hispanicus, Podarcis hispanica and Acanthodactylus erythrurus living in Mediterranean dunes, perhaps indicating that some peculiar abiotic and biotic conditions of these areas constrain the presence of parasite species (Roca \& Lluch, 1988). Moreover, other characteristic of reptile hosts, such as ectothermy, simplicity of the alimentary canal, generalist diet, and low vagility, have been cited as responsible for their depauperate and isolationist helminth communities (Kennedy et al. 1986; Roca \& Hornero, 1994; Martin \& Roca, 2004).

Global prevalences of infection were also very low in $P$. bocagei and $P$. carbonelli. Thus, prevalences of infection of other lacertid lizards in the Iberian Peninsula usually were higher than $45 \%$ and values higher than $60 \%$ were found in lizards from insular ecosystems (Martin \& Roca, 2004). Even the lowest global prevalence found in $L$. $(Z$.) vivipara (39.4\%) (Sanchis et al., 2000) was higher than prevalences found in both hosts from NW Portugal. Host densities and physiography have been pointed out as factors related to high or low values of prevalence. In general, when hosts occur at high densities, they show high prevalences of infection by helminths (Martin \& Roca, 2004). As population densities of both hosts are high in the studied area, it seems that physiography of prospected areas are responsible for the low values of prevalence. In fact, previous studies carried out on P. carbonelli in the W Central System (central Iberian Peninsula) showed a global prevalence of $66.1 \%$ (Roca et al., 1989; Martin \& Roca, 2004), and also showed the presence of some helminth species not found in this research: Nematotaenia tarentolae 
and Mesocestoides sp. (larvae) (Cestoda); Skrjabinodon medinae, Skrjabinelazia pyrenaica and Skrjabinelazia taurica (Nematoda). This fact suggests that different biotopes provide different opportunities for the behaviour of lizards regarding feeding and cohabitation with other species, and also suggests the absence or low frequency, in coastal Portugal, of arthropods that could be intermediate hosts in the life cycles of heteroxenous species, such as $N$. tarentolae, O. gallica, and Skrjabinelazia spp.

Helminth infracommunities (Table 3) and component communities (Tables 1 and 2) of both hosts were very similar, suggesting on the one hand the use of similar biotopes and resources of both hosts (Carretero et al., 2002; unpubl. data), and on the other hand a high degree of interactions among neighbouring populations of $P$. bocagei and $P$. carbonelli. This contrasts with the deep evolutionary divergence $(10-12 \%$ in cyt-b mtDNA, Harris et al., 2002) between both lizard hosts which are not even sister groups but are only related with an ancestor in the early Pliocene (7My) also shared with the NW and SW forms of Podarcis hispanica (Harris et al., 2002; Pinho et al., submitted). Both contrasting results suggest that helminth fauna is a sign of ecological similarity rather than an indicator of evolutionary relationships in this host group.

\section{Acknowledgements}

This study was partially funded by the projects POCTI/ BSE/45664/2002 of Fundaçao para a Ciência e a Tecnologia, FCT (Portugal). M.A.C. was funded by post-doctoral grant (SFRH/BPD/5702/2001) and D.B. by a PhD grant (SFRH/BD/14084/2003), all also from FCT. Collecting permits were provided by Instituto de Conservaçao da Natureza, ICN (Portugal). We thank B. Fráguas, R. Pereira, C. Soares and P. Sousa for helping us with field work. Also Juan E. Martin (University of Valencia) who helped us in the laboratory.

\section{References}

AHO, J. M. (1990): Helminth communities of amphibians and reptiles: Comparative approaches to understanding patterns and processes. In EsCH, G., BuSH, A. and AHO, J. (Eds): Parasite communities: patterns and processes. Chapman and Hall, London

Barbosa, D., Desfilis, E., Carretero, M. A., Font, E. (2005): Chemical stimuli mediate species recognition in Podarcis wall lizards. Amphibia-Reptilia, 26

Bush, A. O., Laferty, K. D., Loft, J. M., Shostak, A. W. (1997): Parasitology meets ecology on its own terms: MARgOlis et al. revisited. J. Parasitol., 83: 575 - 583

Carretero, M. A., Barbosa, D., SÁ-Sousa, P., Harris, D. J. (submitted a): Is the reproductive ecology of Podarcis bocagei and $P$. carbonelli modified when in syntopy?

Carretero, M. A., Barbosa, D., Ribeiro, R., SÁ-Sousa, P., HARRIS, D. J. (2003): Assessing competition by means of fluctuating asymmetry in Podarcis. $12^{\text {th }}$ Ordinary General Meeting, Societas Europaea Herpetologica. St. Pe- tersburg (Russia)

Carretero, M. A., Barbosa, D., SÁ-Sousa, P., Harris, D. J., PINHO, C. (2002): Sintopía estricta entre Podarcis bocagei y P. carbonelli. Bol. Asoc. Herp. Esp., 13: 20 - 24 Carretero, M. A., Ribeiro, R., Barbosa, D., SÁ-Sousa, P. HARRIS, D. J. (submitted b): Spermatogenesis in two Iberian Podarcis lizards: Relationships with male traits. Animal. Biol.

Direcção Geral do Ambiente (1995): Atlas do Ambiente. Direcção Geral do Ambiente, Lisboa

Dollfus, R. PH. (1954): Miscellanea helminthologica maroccana XVIII. Quelques cestodes du groupe Oochoristica auctorum récoltés au Maroc, avec une liste des cestodes des hérissons (Erinaceidae) et une liste des sauriens et ophidiens (exclus Amérique et Australie) où ont été trouvés des Oochoristica. Arch. Inst. Past. Maroc, 11: 657 - 711

Edwards, D. D., Bush, A. O. (1989): Helminth communities in avocets: importance of compound community. $J$. Parasitol., 98: 439 - 445

GarcíA-Adell, G., RocA, V. (1988): Helmintofauna de Lacértidos de los Pirineos Centrales ibéricos. Rev. Ibér. Parasitol., 48: $257-267$

GONZÁlEZ-Moreno, O. (2002): Contribución al conocimiento de la bionomía de digénidos de la familia Brachylaimidae Joyeux et Foley, 1930, en el delta del Llobregat (Barcelona). PhD Thesis, Facultad de Farmacia, Universidad de Barcelona. Barcelona

HANSKI, I. (1982): Dynamics of regional distribution: the core and satellite species hypothesis. Oikos, 38: $210-221$

HARRIS, D. J., SÁ SOUSA, P. (2001): Species distinction and relationships of western Iberian Podarcis lizards (Reptilia, Lacertidae) based on morphology and mitochondrial DNA sequences. Herpetol. J., 11: $129-136$

HARris, D. J., SÁ SouSA, P. (2002): Molecular Phylogenetics of Iberian Wall Lizards (Podarcis): Is Podarcis hispanica a Species Complex? Mol. Phyl. Evol., 23: 75 - 81

Harris, D. J., Carranza, S., Arnold, E. N., Pinho, C., FERRAND, N. (2002): Complex biogeographical distribution of genetic variation within Podarcis Wall lizards across the Strait of Gibraltar. J. Biogeogr., 29: 1257 - 1262 Kaliontzopoulou, A. (2004): Efecto de la simpatría en la morfología de dos especies del género Podarcis en Portugal. D.E.A. dissertation. University of Barcelona

KENNEDY C. R., BAKKE T. A. (1989): Diversity patterns in helminth communities in common gulls, Larus canus. $\mathrm{Pa}$ rasitology, 98: $431-445$

Kennedy, C. R., Bush, A. O., AHO, J. M. (1986): Patterns in helminth communities: Why are birds and fish different? Parasitology, 93: $205-215$

LI, H. C. (1934): Report on a collection of parasitic nematodes, mainly from north China. Part II. Spiruroidea. Trans. Amer. Microsc. Soc., 53: $174-195$

MAgURRAN, A. E. (2004): Measuring biological diversity. Blackwell Publishing, Malden

MARTIN, J. E., RocA, V. (2004): Helminth infracommunities of Gallotia caesaris caesaris and Gallotia caesaris gomerae (Sauria: Lacertidae) from the Canary Islands (Eastern Atlantic). J. Parasitol., 90: 266 - 270 
Martin, J. E., RocA, V. (2005): Helminths of the At-lantic lizard, Gallotia atlantica (Reptilia: Lacertidae), in the Canary Islands (Eastern Atlantic): composition and structure of component communities. Acta Parasitol., 50: $85-89$

PÉreZ-Mellado, V. (1981): Nuevos datos sobre la sistemática y distribución de Podarcis bocagei (Seoane, 1884) (Sauria, Lacertidae) en la Península Ibérica. AmphibiaReptilia, 2: $259-265$

PÉREZ-MEllado, V. (1982): Estructura en una taxocenosis de lacertidae (sauria, reptilia) del sistema central. Mediterránea, 6: $39-64$

PÉREZ-Mellado, V. (1983): Alimentación de dos especies simpátridas de saurios en el Sistema Central, Podarcis hisanica (Steindachner, 1870) y Podarcis bocagei (Seoane, 1884) (Sauria: Lacertidae). Studia Oecologica, 4: 89 - 114 Pinho, C., Ferrand, N., HARris, D. J. (submitted): Reexamination of the Iberian and North African Podarcis phylogeny indicates unusual relative rates of mitochondrial gene evolution in reptiles

Pleguezuelos, J. M., Márquez, R., Lizana, M. (Eds). (2002): Atlas y Libro Rojo de los Anfibios y Reptiles de España. Organismo Autónomo de Parques Nacionales, Madrid

RocA, V. (1985): Contribución al conocimiento de la helmintofauna de los Lacértidos y Gekkónidos del piso termomediterráneo del Levante ibérico. $\mathrm{PhD}$ Thesis, Facultad de Ciencias Biológicas, Universidad de Valencia, Valencia

RocA, V. (1993): Helmintofauna dels reptils. Mon. Soc. Hist. Nat. Balears, 2: $273-292$

RoCA, V., HoRNERO, M. J. (1994): Helminth infracommunities of Podarcis pityusensis and Podarcis lilfordi (Sauria: Lacertidae) from the Balearic Islands (western Mediterranean basin). Can. J. Zool., 72: 658-664
RocA, V., LLuCH, J. (1988): L'helmintofaune des lacertidae (Reptilia) de la zone thermoméditerranéenne de l'est de l'Espagne. Aspects écologiques. Vie Milieu, 38: 201 205

Roca, V., Lluch, J., NAVARro, P. (1986a): Contribución al conocimiento de la helmintofauna de los herpetos ibéricos. I. Parásitos de Lacerta lepida Daudin, 1802 y Podarcis hispanica Steindachner, 1870. Rev. Ibér. Parasitol., 46: $129-136$

Roca, V., Lluch, J., Navarro, P. (1986b): Contribución al conocimiento de la helmintofauna de los herpetos ibéricos. V. Parásitos de Psammodromus algirus (L., 1758) Boulenger, 1887, Psammodromus hispanicus Fitzinger, 1826 y Acanthodactylus erythrurus (Schinz, 1833) Mertens, 1925 (Reptilia: Lacertidae). Bol. R. Soc. Esp. Hist. Nat. (Biol.), 81: $69-78$

RocA, V., López-Balaguer, E., Hornero, M. J. (1989): Helmintofauna de Podarcis hispanica (Steindachner, 1870) y Podarcis bocagei (Seoane, 1884) (Reptilia: Lacertidae) en el Cuadrante Noroccidental de la Península Ibérica. Rev. Ibér. Parasitol., 49: 127 - 135

Sanchis, V., Roig, J. M., Carretero, M. A., Roca, V., Llorente, G. A. (2000): Host-parasite relationships of Zootoca vivipara (Sauria: Lacertidae) in the Pyrenees (North Spain). Folia Parasitol., 47: 118 - 122

SÁ SouSA, P. (2001): Comparative chorology between Podarcis bocagei and P. carbonellae (Sauria: Lacertidae) in Portugal. Rev. Esp. Herp., 15: 85 - 97

SÁ SousA, P., HARris, D. J. (2002): Podarcis carbonelli Pérez-Mellado, 1981 is a distinct species. Amphibia-Reptilia, 23: $459-468$

SHARPILO, V. P. (1976): Parasitic worms of the reptilian fauna of the USSR. Systematics, chorology, biology. Naukoba Dumka, Moscú. 